\title{
Intraspecific Abundance-Occupancy-Patchiness Relations in the Intertidal Benthic Macrofauna of a Cool-Temperate North Sea Mudflat
}

\author{
R. S. K. Barnes ${ }^{1}[0$
}

Received: 28 June 2021 / Revised: 19 August 2021 / Accepted: 23 August 2021 / Published online: 13 September 2021

(C) The Author(s) 2021

\begin{abstract}
The macroecological variable of patchiness (Lloyd's $I_{\mathrm{p}}$ index of patchiness, $P$ ) has recently been shown to be related interand intraspecifically to those of abundance (numbers $\mathrm{m}^{-2}, A$ ), and occupancy (\% occurrence in samples, $O$ ) in lower latitude seagrass macrofaunas. For the first time in higher latitudes, intraspecific relationships between three spatial variables were investigated in the intertidal mudflat macrobenthos of the Scolt Head barrier island, southern North Sea $\left(53^{\circ} \mathrm{N}, 01^{\circ} \mathrm{E}\right)$. Sampling was conducted between early July and late September 2009-2013 using 710- $\mu \mathrm{m}$ mesh for sample processing. Strong positive interspecific $A-O$ and negative interspecific $P-O$ and $P-A$ relationships were present. Two of the most numerous and widespread assemblage components, however, occurred with effectively constant occupancy (Peringia ulvae, 100\%, and Tubificoides benedii, 93\%) across the whole 20-ha locality and therefore could not show intraspecific relationships of occupancy with other macroecological metrics. These two apart, only one other dominant species failed to show a significant positive intraspecific $A-O$ relationship; no species showed significant $P-A$ relations of any form; and only two showed the negative $P-O$ ones that have been described elsewhere. The intraspecific $A-O$ patterns appear to contrast with those of an earlier study at another North Sea locality (the Dutch Wadden Sea), although differences are more apparent than real, but the Scolt Head fauna showed fewer intraspecific $P-O$ and $P-A$ relations than those characterising similar circumstances in the two lower-latitude localities previously investigated. Neither developmental mode nor variation in local abundance appears to influence these patterns. $A-O-P$ relations therefore seem widespread but may be subject to latitudinal modification.
\end{abstract}

Keywords Abundance $\cdot$ Macrobenthos $\cdot$ Mudflat $\cdot$ Occupancy $\cdot$ Patchiness $\cdot$ Scolt head

\section{Introduction}

The interspecific (i.e. between-species) macroecological spatial abundance-occupancy $(A-O)$ relationship is much researched and well-attested across a wide range of habitat types (Verberk et al. 2010; Frisk et al. 2011; Dallas et al. 2019; Miranda and Killgore 2019). Indeed, it has been argued to be one of the most fundamental patterns in ecology (Gaston et al. 2000). The macrobenthic faunas of estuarine and other sheltered coastal mudflats and seagrass beds, for example, seem characterised by such relationships

Communicated by Judy Grassle.

R. S. K. Barnes

rsb1001@cam.ac.uk

1 Department of Zoology and Conservation Research Institute, University of Cambridge, Cambridge, UK
(Foggo et al. 2003; Barnes 2020a, 2021a). Values of occupancy associated with the macrofaunal elements of intertidal seagrass beds in the subtropical Moreton Bay, Australia, and in the warm-temperate Knysna estuarine bay, South Africa, can be predicted with great accuracy solely from local abundance data (Barnes 2021a) using the general $A-O$ expression proposed by He and Gaston (2003). It has also been demonstrated in those same southern-hemisphere seagrass meadows that the dispersion pattern of the invertebrate macrofaunal species, as assessed by the $I_{\mathrm{p}}$ patchiness index of Lloyd (1967) $(P)$, is also negatively related to both their interspecific abundance and occupancy (Barnes 2021a), so that the three macroecological metrics appear interlinked, at least in a seagrass habitat.

The comparable situation with respect to such relationships intraspecifically (i.e. within species), however, appears less straightforward, although it has generally been considered that most $A-O$ patterns are similar intra- and 
interspecifically. Confirmatory evidence for the intraspecific $A-O$ relationship has come largely from studies of vertebrates, especially fish and birds (Gaston et al. 1999; Zuckerberg et al. 2009; Frisk et al. 2011; Faulks et al. 2015), but although its occurrence is also regarded as widespread in other taxa (Gaston et al. 2000), various exceptions have been noted (Blackburn et al. 2006). All the dominant members of the Moreton Bay and Knysna seagrass systems mentioned above that displayed strong interspecific $A-O$ relationships also displayed clear intraspecific ones (Barnes 2021b), but most members of similar macrobenthic soft-sediment assemblages of the cool-temperate Wadden Sea have been recorded as not doing so (Bijleveld et al. 2018). All intraspecific $P$ - $O$ relations within the South African and Australian seagrass species were negative, but only significantly in two-thirds of the species. Whilst most $P$-A ones were also negative, less than half of them were significant (Barnes 2021b). One third of the component seagrass species at those localities showed no significant $P-O$ or $P$ - $A$ correlations.

Blackburn et al. (2006) considered that the strongest $A$ $O$ relationships are likely to be found in marine habitats, but they have relatively rarely been investigated there. To date, the only sites that have supported studies of both interand intraspecific $A-O-P$ relationships are the Moreton Bay and Knysna seagrass beds, whilst the only site with studies of the magnitude of equivalent intraspecific $A-O$ relations amongst the coastal macrobenthos is the Dutch Wadden Sea (Bijleveld et al. 2018). The present work therefore sought to extend this very limited range of intraspecific coastal studies by investigating a northern-hemisphere site similar to the Wadden Sea site: the north Norfolk coast in the UK which also comprises (or before reclamation comprised) a chain of sand-dune barrier islands semi-isolating a small
'Wadden Sea' in their lee that is largely exposed during low tide (Steers 1960). It is known that the macrofauna of a seagrass system there shows the typical strongly positive interspecific $A-O$ relationship, together with weaker negative interspecific $P-O$ and $P-A$ correlations (Barnes 2021a). Hence, it is possible further to explore the generality of $A-O$ $P$ relations by testing at that general site three aspects of the intraspecific patterns: (1) whether Bijleveld et al.'s (2018) 'atypical' $A-O$ results in the Dutch Wadden Sea are replicated in another southern North Sea locality, (2) whether $P-O$ and $P-A$ macroecological patterns are similar in the cool-temperate northern hemisphere to those in the lower latitude, southern hemisphere sites, and (3) whether those individual species that do not seem to conform to the apparent norm of strong positive $A-O$ and less-strong negative $P-O$ patterns also show a common suite of systematic or ecological features.

\section{Methods}

Twelve historical datasets of the intertidal macrobenthic fauna of the 20-ha Cockle Bight mudflat on the sheltered lee side of the Scolt Head Island National Nature Reserve, southern North Sea $\left(52^{\circ} 59^{\prime} 05^{\prime \prime} \mathrm{N}, 00^{\circ} 40^{\prime} 35^{\prime \prime} \mathrm{E}\right)$ (Fig. 1), mostly collected between the summer months of early July to late September in 2009-2013, were available for analysis. Since the mudflat's Zostera noltei seagrass beds and the adjacent unvegetated Arenicola marina dominated muddy sand show essentially the same fauna with only minor differentiation (Barnes 2014), in this study, the two habitats were not distinguished, and the data analysed included both those from the Z. noltei beds and unvegetated flats of Barnes

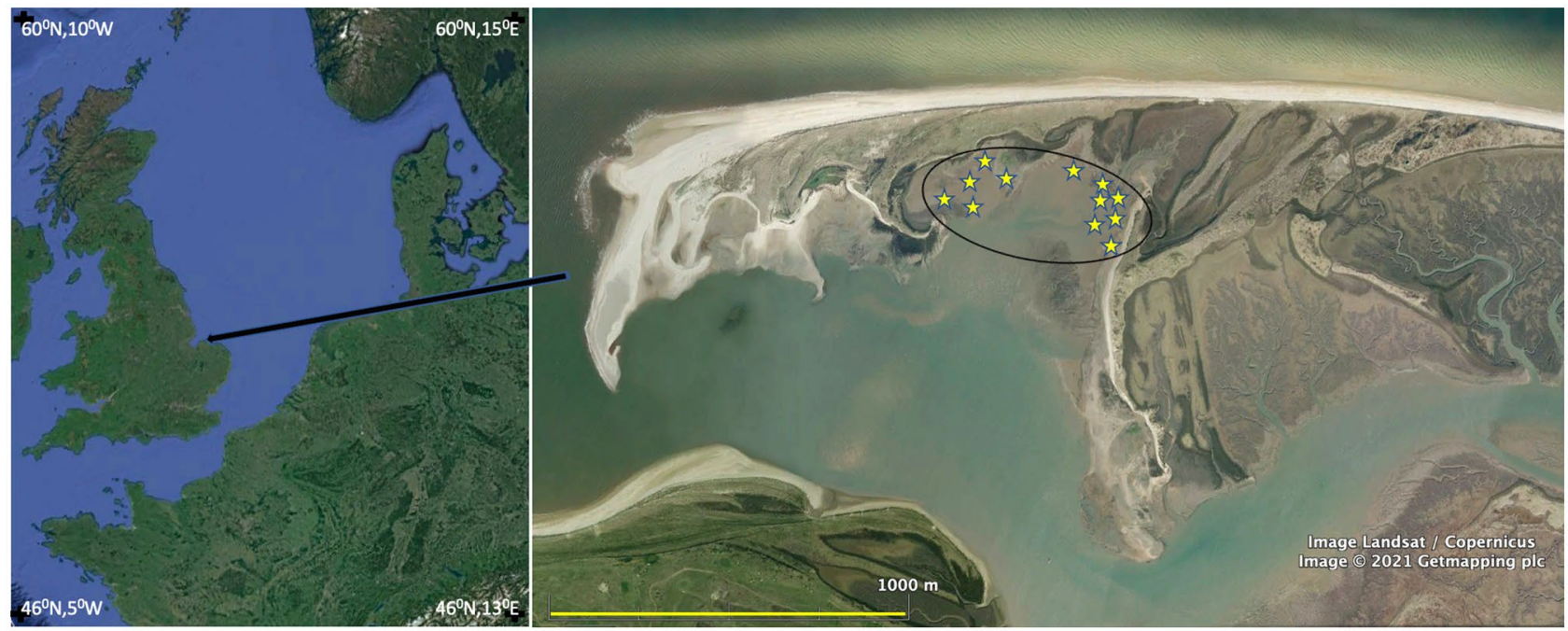

Fig. 1 Location of Cockle Bight mudflat at the western end of Scolt Head barrier island, southern North Sea coast, UK (Google Earth Pro satellite images) 
and Ellwood (2011) and Barnes (2014). This faunal similarity, of course, runs contrary to the general 'vegetated versus unvegetated' paradigm of differential abundance and species richness across the two habitat types (Hemminga and Duarte 2000), but it is typical of the southern North Sea (Polte et al. 2005; Bouma et al. 2009), possibly because of the short-leaved and open nature of the Z. noltei beds there. The qualifications for inclusion of a species in the analyses were its presence (1) in densities of $>1$ ind. in any single core sample in at least six individual datasets, (2) in overall abundances of $>125 \mathrm{~m}^{-2}$, and (3) with overall occupancies of $>20 \%$. Ten such species were present, together comprising $99 \%$ of the total assemblage of individuals and $83 \%$ of the total species occurrences. Analysis of intraspecific patterns was therefore confined to the more widespread and abundant species, not only because confidence in the nature of macroecological metrics assesssed from relatively few samples is low (e.g. Green 1966) but also because $A-O$ relationships at least may be different in rare versus widespread species (Borregaard and Rahbek 2006; Bijleveld et al. 2018), regression slopes being shallower and coefficients of determination $\left(R^{2}\right)$ weaker in the rare category (Freckleton et al. 2006; Buckley and Freckleton 2010).

All samples from the intertidal Cockle Bight macrobenthic assemblage were obtained using the same methodology, involving series of cores each of nominal 60-mm diameter $\left(0.0027-\mathrm{m}^{2}\right.$ area) and 50-mm depth, taken at $1-\mathrm{m}$ intervals across each site, with a minimum of 20 core samples per site and a total of 320 samples. Sampling strategy is always a compromise between number of replicates and number of organisms present in unit sample, and the core crosssectional area was chosen as one that would yield $>100$ individuals per sample (see Barnes and Ellwood 2011). Core depth was selected because most (>98\%) individual macrofauna in such circumstances are known to occur in the uppermost $3 \mathrm{~cm}$ (see, e.g. Klumpp and Kwak 2005; Ysebaert et al. 2005) and expected numbers of the more deeply burrowing species present in the area (Arenicola marina and Heteromastus filiformis) were in any event unlikely to approach $1 \mathrm{core}^{-1}$. Samples were collected during low tide and were gently sieved ('puddled') through $710-\mu \mathrm{m}$ mesh on site. This procedure collects the smaller (mostly $<5 \mathrm{~mm}$ ) and more numerous members of the macrofauna that constitute the large majority of invertebrate biodiversity (Bouchet et al. 2002; Albano et al. 2011), though not the meiofauna nor sessile species attached to the seagrass leaves. Warwick et al. (2006) have shown that different patterning rules may apply to meiofauna and macrofauna, and likewise Davidson et al. (2004) and Leopardas et al. (2014) to sessile species. Retained material from each core was transported immediately to a local laboratory on the island and was there placed in a $30 \times 25-\mathrm{cm}$ white tray in which the living fauna was located by visual examination until no further invertebrates could be observed. Individuals were identified to species level under a binocular microscope, with all organismal nomenclature here being as listed in the World Register of Marine Species (www.marinespecies.org) (Accessed April 2021).

All abundance data are presented as numbers $\mathrm{m}^{-2}$ and for individual species calculation of mean densities at a given site included unoccupied samples (i.e. zero values). Occupancies are percentages of the total samples at a given site in which a species was present. In conformity with the comparable inter- (Barnes 2021a) and intraspecific (Barnes 2021b) data presented earlier for equivalent macrobenthic assemblages in the warm-temperate Knysna estuarine bay and subtropical Moreton Bay (Barnes 2021a,b), dispersion pattern was ascertained by spatial point pattern analysis of count data using Lloyd's $I_{\mathrm{p}}$ index of patchiness (Lloyd 1967), $I_{\mathrm{p}}=[1+1 / k]$, where $k$ is the dispersion parameter of the negative binomial distribution, i.e. $=\left[1+(v-m) / \mathrm{m}^{2}\right]$, ' $m$ ' is the mean abundance across samples and ' $v$ ' is the associated variance. This index has been demonstrated to yield equivalent results to those of the spatially explicit Moran's spatial auto-correlation index for equivalent intertidal macrobenthos (Barnes and Hamylton 2019). It is also independent of sample size over a wide range of area, provided that the individuals are randomly distributed within a patch and that the patches are large relative to sample size (Lloyd 1967; Myers 1978). Granted that the core area was $0.0027 \mathrm{~m}^{2}$, it seems unlikely that macrofaunal patches were smaller than that. Again, to enable direct comparison with the earlier localities mentioned above, occupancy data are also presented in $(\log )$ percentage occurrence form, rather than as logit transformations of proportional data: transformation of occupancy values has no effect on rank $A-O$ or $P-O$ correlations or on the pattern of relative position of individual data points across logarithmic space (and values of $R^{2}$ of power-law relationships are not significantly different: see Barnes 2021b).

The Wadden Sea data of Bijleveld et al. (2018) are available in the form of one value for each of $A$ and $O$ per species per year per tidal basin at http://doi.org/10.5281/ zenodo.1120347, and these were re-analysed for correlations between intraspecific abundance and occupancy.

All calculations were carried out in Microsoft Excel for Mac 16.50 with the StatPlus:mac Pro 7.5.0 add-on, or via PAST 4.04 (Hammer et al. 2020); curves were fitted using KaleidaGraph 5.0; and correlations between metrics are given as Spearman's rank correlation coefficient, $C$. Occupancy data were, however, logit-transformed to test homogeneity of slopes of the $P$ - $O$ relationship by ANCOVA. Powerlaw scaling coefficients (exponents) are abbreviated below to $\beta$ and the associated coefficients of determination of the power-law relationships to $R^{2}$. Statistical probability of departures of values of Lloyd's $I_{\mathrm{p}}$ from 1 were determined by 
Monte Carlo testing with 9999 replicates each with a random distribution of points across samples. To avoid occasions where there might be possible confusion between patchiness $(P)$ and probability, the latter is abbreviated to 'Prob.'

\section{Results}

A total of 38 species was encountered of which 12 were singletons, the remaining 26 , totalling 45,666 individuals, occurring at a mean density of $52,530 \mathrm{~m}^{-2}$ (range $31,455-78,400 \mathrm{~m}^{-2}$ ). This assemblage generally conformed to the sheltered and often estuarine southern North Sea fauna described in detail by Wolff (1973) and Ysebaert et al. (2003). Together, the 26 species displayed both highly significant interspecific $A-O$ and interspecific $P-O$ and $P-A$ relationships (Fig. 2). The overall interspecific $A-O$ relationship (Fig. 2A) showed the same classic positive form seen earlier in the smaller and solely seagrass macrofaunal database from Cockle Bight (Barnes 2021a). The negative $P-A$ and $P-O$ relationships (Fig. 2B), however, were both stronger and of greater significance $(C=-0.73$ and -0.82 c.f. -0.47 and $-0.60 ;$ Prob $=<0.00002$ c.f. 0.06 and $<0.02$; $R^{2}=0.46$ and 0.54 c.f. 0.15 and 0.27 ), while the values of $\beta$ remained comparable. Macrofaunal abundance at each individual site was significantly patchy (all Prob $<0.0001$ ), and overall displayed a Lloyd's $I_{\mathrm{P}}$ of 1.18 (Prob $\left.<0.0001\right)$. The degree of patchiness of the whole assemblage was uniform across all sites (Prob $=0.024)$, as was that of three of the individual species, Peringia ulvae, Tubificoides benedii, and Pygospio elegans (Prob =0.02-0.049) (c.f. Barnes 2020b). Values of neither assemblage abundance nor its patchiness showed any significant correlations across the 12 sites with other macroecological metrics (i.e. $N_{0}$ species density, $N_{2}$ species diversity, or $J$ evenness) (all $C<0.43$, regardless of sign; all Prob >0.17).

Of these almost 46,000 individuals, $79 \%$ were of the one species, Peringia ulvae, which occurred with an occupancy of $100 \%$ (see Electronic Supplementary Material) at a minimum observed density of $2,200 \mathrm{~m}^{-2}(\cong 1$ per 0.00045 $\mathrm{m}^{2}$ ) and a maximum of $>130,000 \mathrm{~m}^{-2}$. Since the value of occupancy for $P$. ulvae was spatially invariant, intraspecific $A-O$ or $P-O$ relationships were not possible. Occurring at such overwhelming densities, $P$. ulvae could conceivably negatively influence the spatial pattern of its sympatric fauna, but the only negative correlation of its numbers with those of any other species was with Ampharete acutifrons (Prob $=0.001)$ and with a $C=-0.18$ in that respect the correlation was very weak. No negative correlation in the entire dataset was other than in the 'none to very weak' category of Moore et al. (2018), as were all positive correlations with the exception of a weak though highly significant one
$(C=0.43$; Prob $<<0.00001)$ between the two canalipalpatan polychaetes Pygospio elegans and Fabricia stellaris.

Intraspecifically, only two of the 10 most abundant and widespread species failed to display a highly significant $A$ $O$ relationship in addition to the Peringia ulvae case above. One of these was Tubificoides benedii which showed almost invariant values of occupancy (occurring in a mean 93\% of samples, and in $100 \%$ of samples at six of the twelve sites) and yet nevertheless achieved a close to significant $A-O$ relationship at $\mathrm{Prob}=0.07$ (Table 1, Fig. 3). Slopes of the relationship differed significantly between the seven species that displayed a significant $A-O$ correlation (ANCOVA $F=3.29$, Prob(same $)=0.008$ ). No species displayed a significant $P$-A correlation (Table 2, Fig. 4). Only two species, T. benedii and A. acutifrons, showed a significant intraspecific $P-O$ relationship (Table 2, Fig. 4), both being negative and with a moderate level of correlation, although values of $\mathrm{R}^{2}$ were relatively low $(<0.5)$. Slopes of the $P-O$ relationships in the two were not significantly different (ANCOVA $F=4.27$, Prob(same) $=0.053$ ). There were no evident differences between the biology of T. benedii and A. acutifrons on the one hand and all the other species on the other that might account for their differential $P-O$ responses. Neither were there any significant correlations within any species between the degree of variation in abundance across sites (as assessed by the relevant coefficient of variance) and the magnitude of the $A-O$ correlation $(C=0.12$, Prob $=0.8)$ or of the associated value of $R^{2}(C=0.35$, Prob $=0.4)$ or magnitude of the $P-O$ correlation $(C=-0.02$, Prob $=0.9)$.

The Wadden Sea dataset of Bijleveld et al. (2018) is not directly comparable with the present ones, but re-analysis of their data for each of the 16 dominant macrofaunal species at that locality shows a significant positive intraspecific correlation between $A$ and $O$ in 14 of the 16 species, highly so in 11 of them $(C=0.50-0.86$, Prob $<<0.00001)$ including Peringia ulvae. Only in Hediste diversicolor and Maculomangus tenuis was there no statistically significant intraspecific $A-O$ correlation $(C<0.25$, Prob $>0.15)$. Comparisons between the frequencies of $P-A-O$ relations observed across the four localities thus far investigated in any of these respects (Scolt Head, Wadden Sea, Knysna and Moreton Bay) are shown in Table 3.

\section{Discussion}

These results suggest that relationships between macrobenthic patchiness, abundance, and occupancy continue into lower latitudes but are less marked than those demonstrated previously in the warm-temperate and subtropical southern hemisphere. They also have a bearing on the conclusions of Bijleveld et al. (2018) on abundance-occupancy relations in the equivalent macrobenthic assemblage in the Wadden Sea. 
Fig. 2 Interspecific $A-O-P$ relationships of macrobenthic species in Cockle Bight mudflat (mean abundance $\mathrm{m}^{-2}$ vs mean \% occupancy of each species), with logarithmic axes and fitted power-laws: $\mathbf{A} A-O$ pattern; $\mathbf{B}$ those of $P-A$ and $P-O$ ( $C=$ Spearman's rank correlation coefficient, and $P=$ probability of $C$ value; $\beta=$ scaling coefficient of fitted power law, and $R^{2}=$ coefficient of determination)
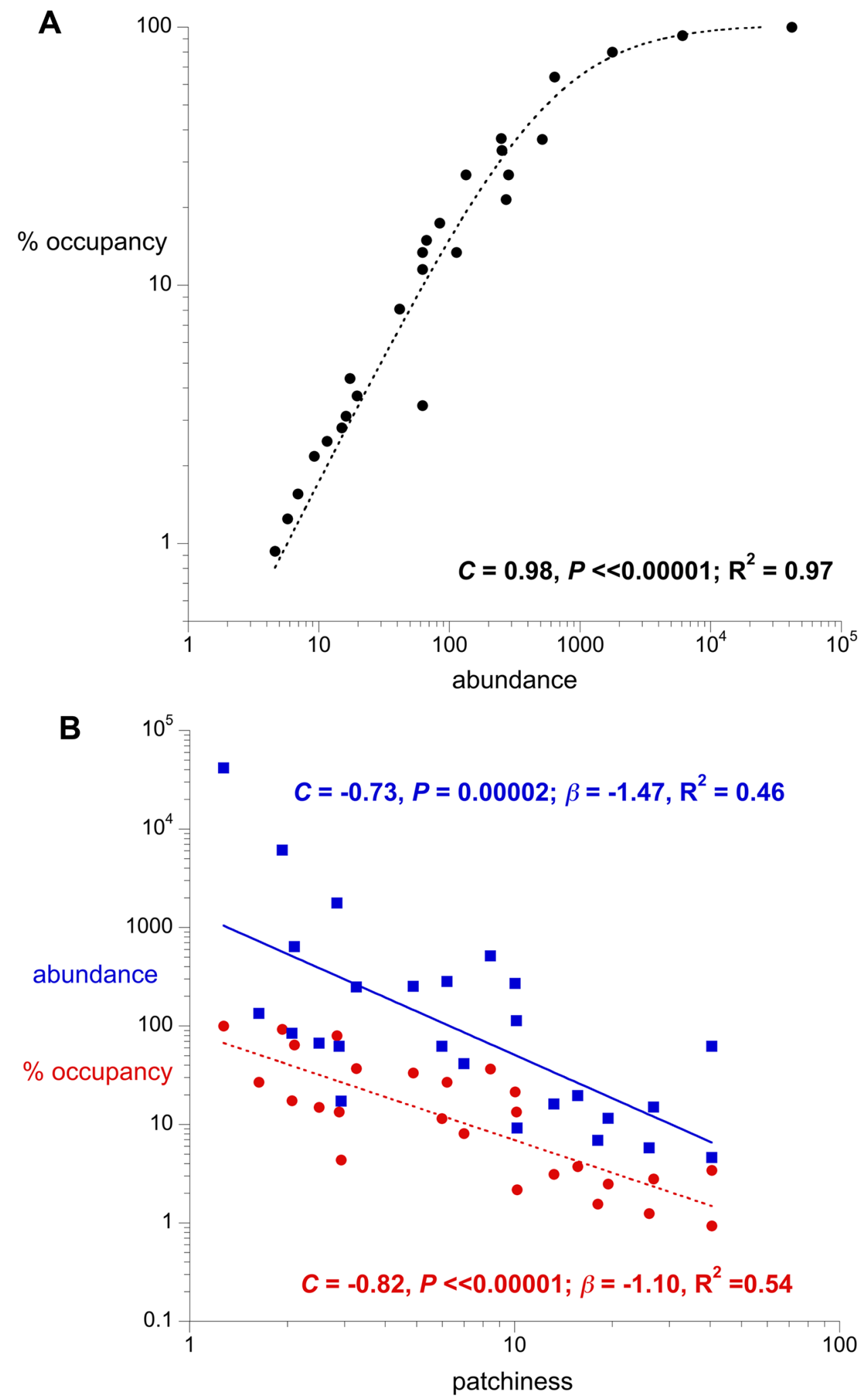

The Dutch Wadden Sea macrofauna investigated by Bijleveld et al. (2018) is similar although not identical to that at the southern North Sea site investigated here. Both have Peringia ulvae as by far the most abundant species, but only three others of the 16 individual Wadden Sea species they studied (Cerastoderma edule, Abra tenuis and Limecola balthica) were amongst the 10 dominant Scolt Head ones, although another six were also present. At face value, the 
Table 1 Intraspecific relations between abundance $(A)$ and occupancy $(O)$ in the 10 most widespread and abundant components of the intertidal macrofaunal assemblage of the Cockle Bight mudflat, Scolt Head Island

\begin{tabular}{lrrllllr}
\hline & \multicolumn{1}{c}{$A$} & $O$ & $C_{A-O}$ & Prob & $\beta$ & $R^{2}$ & $n$ \\
\hline Tubificoides benedii & 6048 & 93 & 0.53 & 0.07 & 0.08 & 0.28 & 12 \\
Tubifex costatus & 669 & 50 & 0.86 & $\mathbf{0 . 0 0 7}$ & $\mathbf{0 . 3 2}$ & $\mathbf{0 . 5 2}$ & 8 \\
Pygospio elegans & 1785 & 80 & 0.80 & $\mathbf{0 . 0 0 2}$ & $\mathbf{0 . 1 6}$ & $\mathbf{0 . 5 9}$ & 12 \\
Ampharete acutifrons & 309 & 30 & 0.97 & $\mathbf{0 . 0 0 0 1}$ & $\mathbf{0 . 6 4}$ & $\mathbf{0 . 7 9}$ & 10 \\
Fabricia stellaris & 483 & 35 & 0.64 & 0.17 & - & 0.93 & 6 \\
Peringia ulvae & 41945 & 100 & - & - & - & - & 12 \\
Cerastoderma edule & 320 & 43 & 0.95 & $\mathbf{0 . 0 0 0 3}$ & $\mathbf{0 . 5 7}$ & $\mathbf{0 . 8 2}$ & 8 \\
Limecola balthica & 174 & 38 & 0.83 & $\mathbf{0 . 0 0 6}$ & $\mathbf{1 . 0 0}$ & $\mathbf{0 . 5 8}$ & 9 \\
Abra tenuis & 665 & 68 & 0.89 & $\mathbf{0 . 0 0 0 3}$ & $\mathbf{0 . 4 1}$ & $\mathbf{0 . 8 3}$ & 11 \\
Carcinus maenas & 329 & 47 & 0.97 & $\mathbf{0 . 0 0 0 1}$ & $\mathbf{0 . 8 1}$ & $\mathbf{0 . 7 3}$ & 8 \\
\hline
\end{tabular}

$A$, mean abundance $\mathrm{m}^{-2}$, and $O$, mean $\%$ occupancy, across qualifying datasets

$C_{A-O}$ rank correlation coefficient between site values of $A$ and $O$, Prob probability of $C_{A-O}$ value; $\beta$ scaling coefficient (power law exponent) where a significant correlation exists, $R^{2}$ coefficient of determination of the power-law fit, $n$ number of qualifying datasets

Significant $A-O$ relationships are in bold results on intraspecific $A-O$ relationships at these two sites appear very different, however. The situation in which two members of the Scolt Head fauna, P. ulvae and Tubificoides benedii, were present in all or virtually all of the 320 individual $0.0027-\mathrm{m}^{2}$ samples and therefore could not participate in relations involving variation in occupancy is clearly very unusual, and excluding those two, only one species (that present in the fewest qualifying datasets) failed to display a significant positive $A-O$ relationship on Scolt Head. In the Wadden Sea, on the other hand, Bijleveld et al. (2018) concluded that although positive spatial $A-O$ relationships were found, overall these were weak (slopes of the relationships being all $<0.33$ ) and only manifested at the spatial scale of the entire $15,000 \mathrm{~km}^{2}$ Wadden Sea. Even at the largest spatial scale, they considered that only seven of the 16 species showed reasonably strong $A-O$ relationships. Changes in such relations across scales have been rarely investigated elsewhere, but in the Knysna estuarine bay, similar though interspecific $A-O$ relationships have certainly been observed in intertidal macrobenthos across different spatial scales, i.e. at landscape (entire estuarine bay), regional (significantly different faunal regions of the bay) and local (individual sites), at least within the bay's total area of $16 \mathrm{~km}^{2}$ (Barnes 2019). The entire scale of the studied Knysna bay, however, would fall within the 'local' scales of Blackburn et al. (2006) and Bijleveld et al. (2018), and data on variation in intraspecific $A-O$ correlations across scales are currently only available for the Wadden Sea.

Differences between the present intraspecific results and those of Bijleveld et al. (2018), however, may be more apparent than real. The research on Scolt Head (together with that at Knysna and Moreton Bay referred to above) sought whether there were significant correlations between observed levels of $A$ and $O$ at a given locality, and if so the form of these relationships. Bijleveld et al. (2018), however, were examining the extent to which the magnitude of one of these variables explained the other, via assessing associated values of $\mathrm{R}^{2}$ and differences between observed and predicted values. Statistically significant correlation does not necessarily indicate that most of the variation is thereby explained, although a mean value of 0.90 for the correlation between $A$ and $O$ for each of the seven species showing significantly correlated values on Scolt Head is not only high but as high as those known from the southern hemisphere. Re-analysis of Bijleveld et al. data indicated that although positive correlations were less marked than those on Scolt Head, values for those species common to both localities showed a highly significant positive correlation (with a mean value of 0.63 ), and, overall, 14 of the Wadden Sea species did indeed show a significant, though moderate, positive correlation of $A$ and $O$, even though the associated values of $R^{2}$ indicated that one accounted for only $30-53 \%$ of the variation in the other.

Spatial variation in abundance is a commonly described feature of intertidal soft-sediment macrofaunal species and assemblages (Bassindale and Clark 1960; Azovsky et al. 2000; Dittman 2002; Zajac 2004; Schenone and Thrush 2020), even across apparently uniform stretches of habitat (Kraan et al. 2009; Barnes and Laurie 2018) and over small distances (Reise 1979; Barnes and Hamylton 2019). Nevertheless, a relationship of such patchiness to $A-O$ patterns has only recently been proposed (Barnes 2019) and to date $P-A-O$ correlations have only been investigated at three widely separated localities. The increasing latitudinal sequence of these, i.e. Moreton Bay $\rightarrow$ Knysna $\rightarrow$ North Sea, shows decreasing levels of intraspecific $P-A$ and $P-O$ relations, as well as increasing assemblage abundance $(<3000$ to $>50,000 \mathrm{~m}^{-2}$ ), decreasing overall species density $(>200$ to $<40)$, and increasing mean occupancy $(<12$ to $>20 \%)$ 

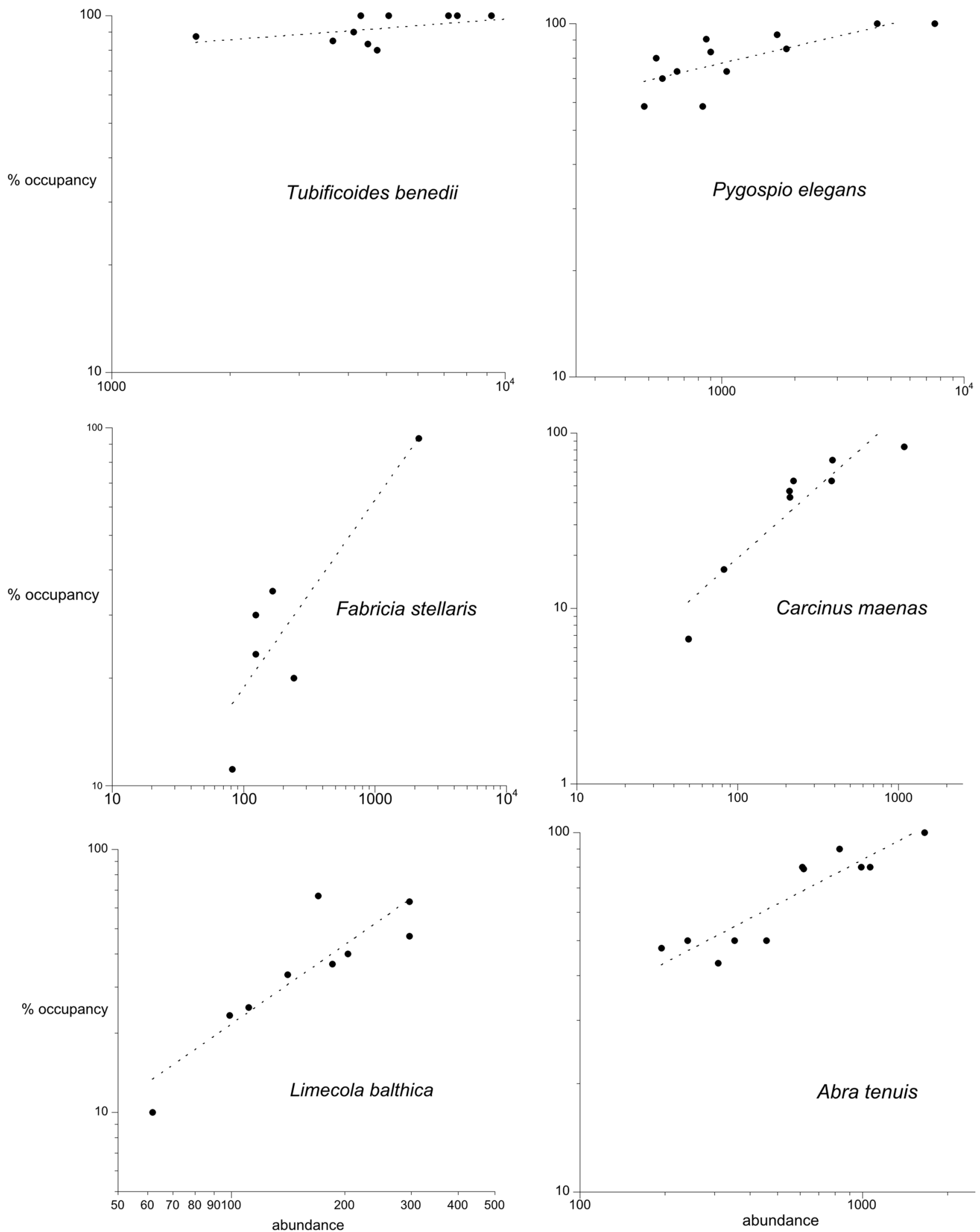

Fig. 3 Representative intraspecific $A-O$ relationships of dominant members of Cockle Bight macrobenthos, with logarithmic axes and fitted power laws (see Table 1) 
Table 2 Intraspecific relations between $I_{\mathrm{p}}$ patchiness $(P)$, and the other two measured macroecological variables, abundance $(A)$ and occupancy $(O)$, in the 10 most abundant and widespread components of the intertidal macrofaunal assemblage of the Cockle Bight mudflat, Scolt Head Island

\begin{tabular}{|c|c|c|c|c|c|c|c|c|c|c|c|c|}
\hline & $I_{\mathrm{p}}(P)$ & $A$ & $C_{\text {P-A }}$ & Prob & $\beta$ & $R^{2}$ & $O$ & $C_{\mathrm{P}-\mathrm{O}}$ & Prob & $\beta$ & $R^{2}$ & $n$ \\
\hline Tubificoides benedii & 1.60 & 6048 & -0.17 & 0.59 & - & - & 93 & -0.63 & 0.03 & -0.19 & 0.41 & 12 \\
\hline Tubifex costatus & 2.58 & 669 & 0.57 & 0.14 & - & - & 50 & 0.21 & 0.61 & - & - & 8 \\
\hline Pygospio elegans & 1.45 & 1785 & 0.07 & 0.81 & - & - & 80 & -0.33 & 0.29 & - & - & 12 \\
\hline Ampharete acutifrons & 4.30 & 309 & -0.54 & 0.11 & - & - & 30 & -0.65 & 0.04 & -0.83 & 0.16 & 10 \\
\hline Fabricia stellaris & 3.47 & 483 & -0.23 & 0.66 & - & - & 35 & -0.77 & 0.07 & - & - & 6 \\
\hline Peringia ulvae & 1.15 & 41945 & -0.20 & 0.53 & - & - & 100 & - & - & - & - & 12 \\
\hline Cerastoderma edule & 1.59 & 320 & 0.12 & 0.78 & - & - & 43 & -0.07 & 0.87 & - & - & 8 \\
\hline Limecola balthica & 1.83 & 174 & -0.15 & 0.70 & - & - & 38 & -0.13 & 0.73 & - & - & 8 \\
\hline Abra tenuis & 1.38 & 665 & 0.22 & 0.52 & - & - & 68 & -0.06 & 0.85 & - & - & 11 \\
\hline Carcinus maenas & 2.12 & 329 & -0.38 & 0.35 & - & - & 47 & -0.49 & 0.22 & - & - & 8 \\
\hline
\end{tabular}

$I_{\mathrm{p}}(P)$ mean Lloyd's index of patchiness

$A$ mean abundance $\mathrm{m}^{-2}$ and $O$ mean $\%$ occupancy, across qualifying datasets

$C$ rank correlation coefficient, Prob probability of $C$ value (with probabilities $<0.05$ shown in bold), $\beta$ scaling coefficient (power law exponent) where a significant correlation exists, $R^{2}$ coefficient of determination of the power-law fit, $n$ number of qualifying datasets

All values of $I_{\mathrm{p}}(P)$ indicate significantly patchy dispersion (all Prob $\left.<0.004\right)$
(Barnes 2021a and present paper). The level of overall assemblage patchiness, however, was the same across all three systems, at Lloyd's $I_{\mathrm{p}}$ values of 1.15-1.18 (Barnes 2020a, 2021a). Although fewer species on Scolt Head showed significant intraspecific $A-O$ correlations than at the lower latitude sites, the magnitude of those that were significant was comparable, i.e. $C=0.90$ and $R^{2}=0.69$ on Scolt Head versus mean values of $C=0.90$ and $R^{2}=0.81$ across the Moreton Bay and Knysna localities (Barnes 2021a). The equivalent values for the significant $P-O$ relationships at Moreton Bay and Knysna were lower than for $A-O$ at mean values of $C=(-) 0.70$ and $R^{2}=0.49$ (Barnes 2021a), and the only two datapoints available for $P-O$ from Scolt Head were both lower still.

Overall assemblage abundance appears remarkably constant at the Moreton Bay locality, measured at the same time each year from 2011 to 2018 having a range of only 2300-2600 m $\mathrm{m}^{-2}$ (Barnes and Hamylton 2019); the present data from Scolt Head, in contrast, had a mean of 52,530 and a range of 31,455-78,340 $\mathrm{m}^{-2}$. Spatial and/or temporal variation in abundance correlates with equivalent variation in occupancy under positive $A-O$ relationships (He and Gaston 2003), and such variation has in turn been correlated with fluctuations in local recruitment, for example in the Wadden Sea (Bijleveld et al. 2018). Hence, attempts have been made to correlate this intraspecific spatial variation with juvenile dispersal rates (Holt et al. 2002; Foggo et al. 2007; Webb et al. 2009). Abra tenuis, for example, deposits its eggs in the sediment (Holmes et al. 2004) and shows poorer dispersal than the otherwise ecologically similar tellinoid Limecola balthica that spawns into the overlying water (Honkoop and van der Meer 1997). Correspondingly, A. tenuis showed the weaker $A-O$ relationship in the Wadden Sea (Bijleveld et al. 2018). On Scolt Head, however, both species had highly significant $A-O$ relationships and $L$. balthica displayed the lower value of $R^{2}$. The only species not to show a significant intraspecific $A-O$ relationship on Scolt Head (other than the omnipresent $P$. ulvae and $T$. benedii) was indeed the non-planktonic brooder Fabricia stellaris (Rouse 1995). But Tubifex costatus, Pygospio elegans and Ampharete acutifrons are all species with very limited dispersal (Birtwell and Arthur 1980; Price and Warwick 1980; Kesäniemi et al. 2012; Thonig et al. 2017), and they all displayed the same relationship as those with dispersive planktonic larvae. Further, the available database for $F$. stellaris was smaller than those of all the other species and this may have been responsible for failure to achieve statistical significance. Thus, there was no clear separation of $A-O$ response based on reproduction mode among the Scolt Head species, nor indeed among those in Moreton Bay or Knysna (Barnes 2021b).

Neither was there a correlation between degree of variation in local population density (as assessed by the coefficients of variation in abundance) and $P-O$ relationship across the Scolt Head sites, nor across the species at the three contrasting localities so far investigated $(C=-0.02$, Prob $=0.9$ ). There was also no evidence that members of the same group of invertebrates with, as far as is known similar ecologies, reacted in a similar fashion across sites 

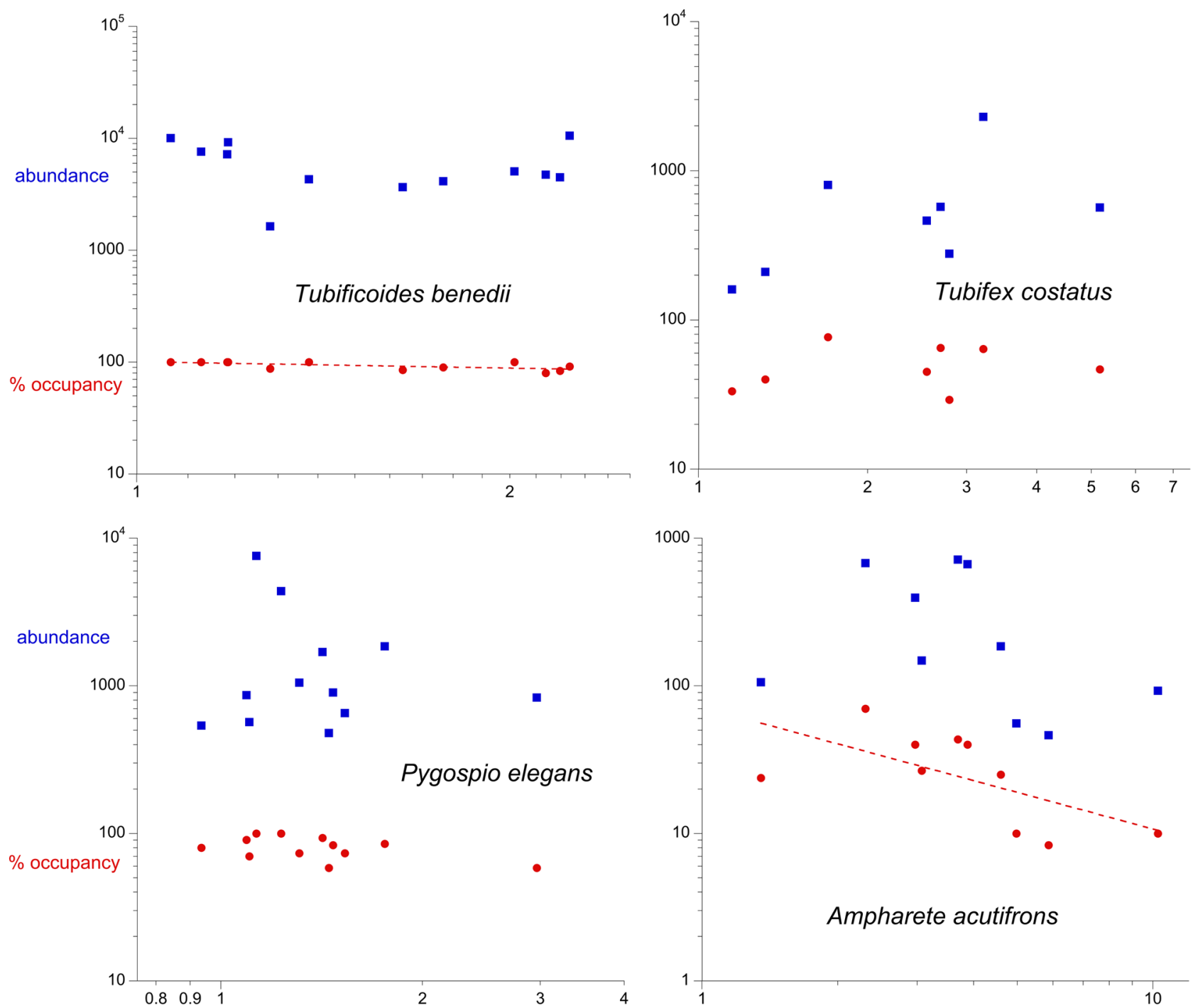

Ampharete acutifrons
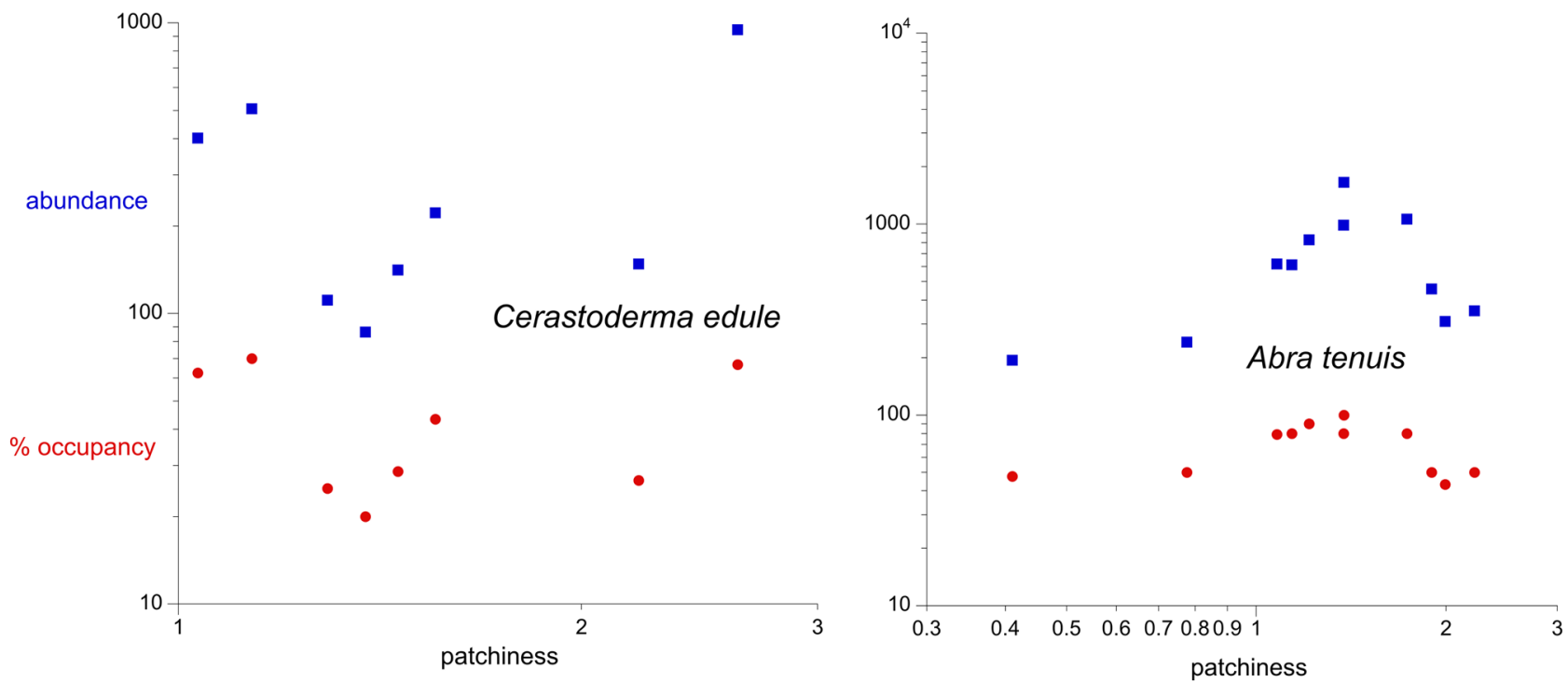

Fig. 4 Representative intraspecific $P-A$ and $P-O$ relationships of dominant members of Cockle Bight macrobenthos. Power laws are fitted only where the correlation is statistically significant at Prob $<0.05$ (see Table 2) 
Table 3 Percentage of tested dominant intertidal muddy sandflat/seagrass macrofaunal species showing significant intraspecific $A-O, P-A$ and $P-O$ correlations at different localities

\begin{tabular}{lrlrrrl}
\hline & $A-O$ & $C_{A-O}(\mathrm{SE})$ & $P-A$ & $P-O$ & $n$ & Source \\
\hline Moreton Bay $\left(27^{\circ} \mathrm{S}\right)$ & 100 & $0.88(0.03)$ & \multicolumn{1}{c}{42} & 75 & 12 & Barnes 2021b \\
Knysna estuarine bay $\left(34^{\circ} \mathrm{S}\right)$ & 100 & $0.92(0.01)$ & 33 & 60 & 15 & Barnes 2021b \\
Scolt Head Island $\left(53^{\circ} \mathrm{N}\right)$ & 70 & $0.83(0.05)$ & 0 & 20 & 9 & This paper \\
Wadden Sea $\left(53^{\circ} \mathrm{N}\right)$ & 87 & $0.58(0.05)$ & - & - & 16 & $\begin{array}{c}\text { This paper from } \\
\text { Bijleveld et al. } \\
\end{array}$ \\
& & & & & & 2018 \\
\hline
\end{tabular}

$C_{A-O}$ mean rank correlation coefficient between $A$ and $O$ (with standard error, SE)

$n$ number of species for which data were available or localities. Tubifex costatus did not show a $P-O$ relationship but Tubificoides benedii did; likewise Prionospio sexoculata at Knysna and Malacoceros sp. in Moreton Bay did, but Pygospio elegans on Scolt Head did not; and Pseudofabricia sp. at Knysna did, whilst Fabricia stellaris on Scolt Head did not. The clear exception is that all heterodont bivalves in the investigated faunas (Dosinia hepatica and Salmacoma litoralis at Knysna, and Cerastoderma edule, Abra tenuis and Limecola balthica on Scolt Head) failed to display any $P-O$ relationship, although all did show the $A-O$ one, as indeed did the same species in the Wadden Sea. As only the three localities have been investigated to date, it is too early to know the extent to which this is truly reflects the general response of these species.

It is clear, however, as Bijleveld et al. (2018) pointed out, that although the interspecific $A-O$ relationship may be sufficiently strong to permit accurate estimation of the level of $O$ solely from that of $A$, that is not the case with the intraspecific one; and $P-O$ and $P-A$ relationships are weaker still. Nevertheless, within intertidal estuarine and coastal mud- and sandflats, the macrofauna may display very close interspecific $A-O$ relationships, and many if not all the dominant components of these assemblages also display corresponding intraspecific $A-O$ and $P-O$ patterns. The fact that significant intraspecific $A-O-P$ relationships do occur, even if they are of lesser magnitude than interspecific ones, therefore requires explanation. So, perhaps to an even greater degree, do exceptions to the apparent generalities, since a number of the dominant species do not show some, or potentially any, such patterns. An explanation for this is not yet evident, and neither is whether the potential latitudinal gradient in $P-O$ and $P-A$ relationships shown in Table 3 is real. Further investigation of these exceptions, of the relationships between patchiness of the macrofauna and of their microphytobenthic food base (see, e.g. Daggers et al. 2020), and of more localities in total are obviously needed before explanation of the nature of intraspecific $A-O$ and $\mathrm{P}-\mathrm{O}$ responses is possible.
Supplementary Information The online version contains supplementary material available at https://doi.org/10.1007/s12237-021-00998-z.

Acknowledgements I am most grateful to Michael Rooney and Natural England for use of the facilities of the Watcher's Hut on Scolt Head Island and for permission to sample in an English National Nature Reserve.

Author Contribution RSKB conceived, designed and executed this study and wrote the manuscript. No other person is entitled to authorship.

Data Availability All data generated or analysed during this study are included in this published article and its supplementary information files.

\section{Declarations}

Conflict of interest The author declares no competing interests.

Ethical Approval All applicable international, national and/or institutional guidelines for sampling, care and experimental use of organisms for the study were followed and all necessary permissions and approvals were obtained in respect of the original collections of the data.

Consent for Publication The author consents to publication.

Open Access This article is licensed under a Creative Commons Attribution 4.0 International License, which permits use, sharing, adaptation, distribution and reproduction in any medium or format, as long as you give appropriate credit to the original author(s) and the source, provide a link to the Creative Commons licence, and indicate if changes were made. The images or other third party material in this article are included in the article's Creative Commons licence, unless indicated otherwise in a credit line to the material. If material is not included in the article's Creative Commons licence and your intended use is not permitted by statutory regulation or exceeds the permitted use, you will need to obtain permission directly from the copyright holder. To view a copy of this licence, visit http://creativecommons.org/licenses/by/4.0/. 


\section{References}

Albano, P.G., B. Sabelli, and P. Bouchet. 2011. The challenge of small and rare species in marine biodiversity surveys: Microgastropod diversity in a complex tropical coastal environment. Biodiversity and Conservervation 20: 3223-3237. https://doi.org/10.1007/ s10531-011-0117-x.

Azovsky, A.I., M.V. Chertoprood, N.V. Kucheruk, P.V. Rybnikov, and F.V. Sapozhnikov. 2000. Fractal properties of spatial distribution of intertidal benthic communities. Marine Biology 136: 581-590. https://doi.org/10.1007/s002270050718.

Barnes, R.S.K. 2014. Is spatial uniformity of soft-sediment biodiversity widespread and if so, over what scales? Marine Ecology Progress Series 504: 147-158. https://doi.org/10.3354/meps 10770.

Barnes, R.S.K. 2019. Abundance/occupancy/patchiness relations in estuarine seagrass macrobenthos. Estuarine, Coastal and Shelf Science 228: 106360. https://doi.org/10.1016/j.ecss.2019.106360.

Barnes, R.S.K. 2020a. Do different sympatric seagrasses support macrobenthic faunas of differing composition, abundance, biodiversity of patchiness? Marine Environmental Research 160: 104983. https://doi.org/10.1016/j.marenvres2020.104983.

Barnes, R.S.K. 2020b. Do species display characteristic intraspecific levels of patchiness in a given habitat type? The case of intertidal seagrass macrobenthos. Marine Biology 167: 177. https://doi.org/ 10.1007/s00227-020-03793-9.

Barnes, R.S.K. 2021a. Interspecific relationship of patchiness to occupancy and abundance, as exemplified by seagrass macrobenthos. Ecological Indicators 121: 107083. https://doi.org/10.1016/jecol ind.2020.107083.

Barnes, R.S.K. 2021b. Within-species relationship of patchiness to both abundance and occupancy, as exemplified by seagrass macrobenthos. Oecologia 196: 1107-1117. https://doi.org/10.1007/ s00442-021-04985-w.

Barnes, R.S.K., and M.D.F. Ellwood. 2011. Macrobenthic assemblage structure in a cool-temperate intertidal dwarf eelgrass bed in comparison with those from lower latitudes. Biological Journal of the Linnean Society 104: 527-540. https://doi.org/10.1111/j.10958312.2011.01738.x.

Barnes, R.S.K., and S.M. Hamylton. 2019. Isometric scaling of faunal patchiness: Seagrass macrobenthic abundance across small spatial scales. Marine Environmental Research 146: 89-100. https://doi. org/10.1016/j.marenvres.2019.03.011.

Barnes, R.S.K., and H. Laurie. 2018. Seagrass macrofaunal abundance shows both multifractality and scale-invariant patchiness. Marine Environmental Research 138: 84-95. https://doi.org/10.1016/j. marenvres.2018.04.009.

Bassindale, R., and R.B. Clark. 1960. The Gann flat, dale: Studies on the ecology of a muddy beach. Field Studies 1 (2): 1-22.

Bijleveld, A.I., T.J. Compton, L. Klunder, S. Holthuijsen, J. ten Horn, A. Koolhaas, A. Dekinga, J. van der Meer, and H.W. van der Veer. 2018. Presence-absence of marine macrozoobenthos does not generally predict abundance and biomass. Science Reports 8: 3039. https://doi.org/10.1038/s41598-018-21285-1.

Birtwell, I.K., and D.R. Arthur. 1980. The ecology of tubificids in the Thames Estuary with particular reference to Tubifex costatus (Claparède). In: Aquatic Oligochaete Biology, eds. R.O Brinkhurst, and D.G. Cook, 331-381. Boston MA: Springer. https://doi.org/10.1007/978-1-4613-3048-6_18

Blackburn, T.M., P. Cassey, and K.J. Gaston. 2006. Variations on a theme: Sources of heterogeneity in the form of the interspecific relationship between abundance and distribution. Journal of
Animal Ecology 75: 1426-1439. https://doi.org/10.1111/j.13652656.2006.01167.x.

Borregaard, M.K., and C. Rahbek. 2006. Prevalence of intraspecific relationships between range size and abundance in Danish birds. Diversity and Distributions 12: 417-422. https://doi.org/10. 1111/j.1366-9516.2006.00258.x.

Bouchet, P., P. Lozouet, P. Maestrati, and V. Heros. 2002. Assessing the magnitude of species richness in tropical marine environments: Exceptionally high numbers of molluscs at a New Caledonia site. Biological Journal of the Linnean Society 75: 421-436. https:// doi.org/10.1046/j.1095-8312.2002.00052.x.

Bouma, T.J., V. Ortells, and T. Ysebaert. 2009. Comparing biodiversity effects among ecosystem engineers of contrasting strength: Macrofauna diversity in Zostera noltii and Spartina anglica vegetations. Helgoland Marine Research 63: 3-18. https://doi.org/10. 1007/s10152-008-0133-8.

Buckley, H.L., and R.P. Freckleton. 2010. Understanding the role of species dynamics in abundance-occupancy relationships. Journal of Ecology 98: 645-658. https://doi.org/10.1111/j.1365-2745. 2010.01650.x.

Daggers, T.D., D. van Oevelen, P.M.J. Herman, H.T.S. Boschker, and D. van der Wal. 2020. Spatial variability in macrofaunal diet composition and grazing pressure on microphytobenthos in intertidal areas. Limnology and Oceanography 65: 2819-2834. https://doi. org/10.1002/lno.11554.

Dallas, T.A., J. Pöyry, R. Leinonen, and O. Ovaskainen. 2019. Temporal sampling and abundance measurement influences support for occupancy-abundance relationships. Journal of Biogeography 46: 2839-2849. https://doi.org/10.1111/jbi.13718.

Davidson, I.C., A.C. Crook, and D.K.A. Barnes. 2004. Quantifying spatial patterns of intertidal biodiversity: Is movement important? Marine Ecology 25: 15-34. https://doi.org/10.1111/j.1439-0485. 2004.00015.x.

Dittman, S. 2002. Benthic fauna in tropical tidal flats-A comparative perspective. Wetlands Ecology and Management 10: 189-195. https://doi.org/10.1023/A:1020119512225.

Faulks, L., R. Svanbäck, H. Ragnarsson-Stabo, P. Eklöv, and Ö. Östman. 2015. Intraspecific niche variation drives abundanceoccupancy relationships in freshwater fish communities. American Naturalist 186: 272-283. https://doi.org/10.1086/682004.

Foggo, A., D.T. Bilton, and S.D. Rundle. 2007. Do developmental mode and dispersal shape abundance-occupancy relationships in marine invertebrates? Journal of Animal Ecology 76: 695-702. https://doi.org/10.1111/j.1365-2656.2007.01245.x.

Foggo, A., M.T. Frost, and M.J. Attrill. 2003. Abundance-occupancy patterns in British estuarine macroinvertebrates. Marine Ecology Progress SerIes 265: 297-302. https://doi.org/10.3354/ meps265297.

Freckleton, R.P., D. Noble, and T.J. Webb. 2006. Distributions of habitat suitability and the abundance-occupancy relationship. American Naturalist 167: 260-275. https://doi.org/10.1086/ 498655.

Frisk, M.G., D.E. Duplisea, and V.M. Trenkel. 2011. Exploring the abundance-occupancy relationships for the Georges Bank finfish and shellfish community from 1963 to 2006 . Ecological Applications 21: 227-240. https://doi.org/10.1890/09-1698.1.

Gaston, K.J., T.M. Blackburn, and R.D. Gregory. 1999. Intraspecific abundance-occupancy relationships: Case studies of six bird species in Britain. Diversity and Distributions 5: 197-212. https:// doi.org/10.1046/j.1472-4672-4642.1999.00054.x.

Gaston, K.J., T.M. Blackburn, J.J.D. Greenwood, R.D. Gregory, and R.M.J.H. QuinnLawton. 2000. Abundance-occupancy 
relationships. Journal of Applied Ecology 37 (Suppl 1): 39-59. https://doi.org/10.1046/j.1365-2664.2000.00485.x.

Green, R.H. 1966. Measurement of non-randomness in spatial distributions. Researches in Population Ecology 8: 1-7. https://doi.org/ 10.1007/BF02524740.

Hammer, Ø., D.A.T. Harper, and P.D. Ryan. 2020. PAST: Paleontological statistics software package for education and data analysis. Version 4: 04.

He, F., and K.J. Gaston. 2003. Occupancy, spatial variance and the abundance of species. American Naturalist 162: 366-375. https:// doi.org/10.1086/377190.

Hemminga, M.A., and C.M. Duarte. 2000. Seagrass ecology. Cambridge: Cambridge University Press.

Holmes, S.P., R. Dekker, and I.D. Williams. 2004. Population dynamics and genetic differentiation in the bivalve mollusc Abra tenuis: Aplanic dispersal. Marine Ecology Progress Series 268: 131-140. https://doi.org/10.3354/meps268131.

Holt, A.R., K.J. Gaston, and F. He. 2002. Occupancy-abundance relationships and spatial distribution: A review. Basic and Applied Ecology 3: 1-13. https://doi.org/10.1078/1439-1791-00083.

Honkoop, P.J.C., and J. van der Meer. 1997. Reproductive output of Macona balthica populations in relation to winter-temperature and intertidal-height mediated changes of body mass. Marine Ecology Progress Series 149: 155-162. https://doi.org/10.3354/ meps149155.

Kesäniemi, J., W. Geuverink, and K.E. Knott. 2012. Polymorphism in developmental mode and its effect on population genetic structure of a spionid polychaete, Pygospio elegans. Integrative and Comparative Biology 52: 181-196. https://doi.org/10.1093/icb/ics064.

Klumpp, D.W., and S.N. Kwak. 2005. Composition and abundance of benthic macrofauna of a tropical sea-grass bed in North Queensland, Australia. Pacific Science 59: 541-560. https://doi.org/10. 1353/psc.2005.0046.

Kraan, C., J. van der Meer, A. Dekinga, and T. Piersma. 2009. Patchiness of macrofaunal invertebrates in homogenized intertidal habitats: Hidden spatial structure at a landscape scale. Marine Ecology Progress Series 383: 211-224. https://doi.org/10.3354/ meps07994.

Leopardas, V., W. Uy, and M. Nakaoka. 2014. Benthic macrofaunal assemblages in multispecific seagrass meadows of the southern Philippines: Variation among vegetation dominated by different seagrass species. Journal of Experimental Marine Biology and Ecology 457: 71-80. https://doi.org/10.1016/j.jembe.2014.04.006.

Lloyd, M. 1967. Mean crowding. Journal of Animal Ecology 36: 1-30. https://doi.org/10.2307/3012.

Miranda, L.E., and K.J. Killgore. 2019. Abundance-occupancy patterns in a riverine fish assemblage. Freshwater Biology 64: 2221-2233. https://doi.org/10.1111/fwb.13408.

Moore, D.S., W.I. Notz, and M. Fligner. 2018. The basic practice of statistics $8 E$. New York: Freeman.

Myers, J.H. 1978. Selecting a measure of dispersion. Environmental Entomology 7: 619-621. https://doi.org/10.1093/ee/7.5.619.

Polte, P., A. Schanz, and H. Asmus. 2005. The contribution of seagrass beds (Zostera noltii) to the function of tidal flats as juvenile habitat for dominant epibenthos in the Wadden Sea. Marine Biology 147: 813-822. https://doi.org/10.1007/s00227-005-1583-z.
Price, R., and R.M. Warwick. 1980. Temporal variations in annual production and biomass in estuarine populations of two polychaetes, Nephtys hombergi and Ampharete acutifrons. Journal of the Marine Biological Association of the UK 60: 481-487. https:// doi.org/10.1017/S0025315400028496.

Reise, K. 1979. Spatial configurations generated by motile polychaetes. Helgoländer Wissenschaftliche Meeresuntersuchungen 32: 55-72. https://doi.org/10.1007/BF02189892.

Rouse, G. 1995. Spermathecae of Fabricia and Manayunkia (Sabellidae, Polychaeta). Invertebrate Biology 114: 248-255. https://doi. org/10.2307/3226879.

Schenone, S., and S.F. Thrush. 2020. Unraveling ecosystem functioning in intertidal soft sediments: The role of density-driven interactions. Scientific Reports 10: 11909. https://doi.org/10.1038/ s41598-020-68869-4.

Steers, J.A. 1960. Physiography and evolution. In Scolt Head Island, revised, ed. J.A. Steers, 12-66. Cambridge: Heffer \& Sons.

Thonig, A., G.T. Banta, B.W. Hansen, and K.E. Knott. 2017. Seasonal genetic variation associated with population dynamics of a poecilogonous polychaete worm. Ecology and Evolution 7: 10005-10017. https://doi.org/10.1002/ece3.3518.

Verberk, W.C.E.P., G. van der Velde, and H. Esselink. 2010. Explaining abundance-occupancy relationships in specialists and generalists: A case study on aquatic macroinvertebrates in standing waters. Journal of Animal Ecology 79: 589-601. https://doi.org/10.1111/j. 1365-2656.2010.01660.x.

Warwick, R.M., S.L. Dashfield, and P.J. Somerfield. 2006. The integral structure of a benthic infaunal assemblage. Journal of Experimental Marine Biology and Ecology 330: 12-18. https://doi.org/10. 1016/j.jembe.2005.12.013.

Webb, T.J., E.H.M. Tyler, and P.J. Somerfield. 2009. Life history mediates large-scale population ecology in marine benthic taxa. Marine Ecology Progress Series 396: 293-306. https://doi.org/ $10.3354 /$ meps08253.

Wolff, W.J. 1973. The estuary as a habitat. An analysis of data on the soft-bottom macrofauna of the estuarine area of the rivers Rhine, Meuse, and Scheldt. Zoologische Verhandelingen 126: 3-242.

Ysebaert, T., P.H.J. Herman, P. Meire, J. Craeymeersch, H. Verbeek, and C.H.R. Heip. 2003. Large-scale spatial patterns in estuaries: Estuarine macrobenthic communities in the Schelde estuary, NW Europe. Estuarine, Coastal and Shelf Science 57: 335-355. https://doi.org/10.1016/S0272-7714(02)00359-1.

Ysebaert, T., M. Fettweis, P. Meire, and M. Sas. 2005. Benthic variability in intertidal soft-sediments in the mesohaline part of the Schelde estuary. Hydrobiologia 540: 197-216. https://doi.org/10. 1007/s10750-004-7144-5.

Zajac, R.N. 2004. Macrofaunal responses to pit-mound patch dynamics in an intertidal mudflat: Local versus patch-type effects. Journal of Experimental Marine Biology and Ecology 313: 297-315. https://doi.org/10.1016/j.jembe.2004.08.011.

Zuckerberg, B., W.F. Porter, and K. Corwin. 2009. The consistency and stability of abundance-occupancy relationships in large-scale population dynamics. Journal of Animal Ecology 78: 172-181. https://doi.org/10.1111/j.1365-2656.2008.01463.x. 